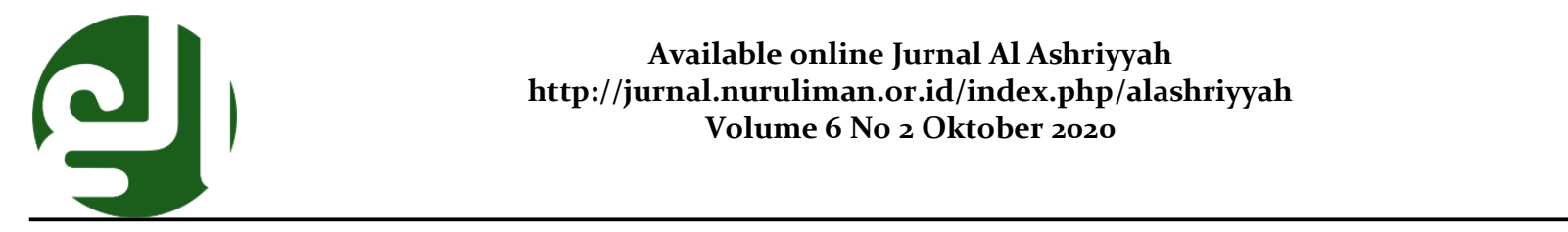

\title{
MORALITAS KEMANUSIAAN BERDASARKAN FAKTA SOSIAL ÉMILE DURKHEIM DAN AYAT-AYAT SOSIAL M. QURAISH SHIHAB
}

\author{
Aceng Fuad Hasim Ikbal, Mulawarman Hannase, Abd. Muid \\ Pasca Sarjana PTIQ Jakarta Tahun 2019 \\ Email: acengfuad39@gmail.com \\ E-mail:
}

No. Tlp/WA:

Diterima: 8 Agustus 2020; Diperbaiki: 20 Agustus 2020; Disetujui: 28 Agustus 2020

\begin{abstract}
This article aims to see how the formation of human morality is seen from the social facts of mile Durkheim and the social verses of $M$. Quraish Shihab. This study uses a phenomenological approach by linking fundamental principles, namely objective reality and social reality which are integrated with traditionalist and modernist objectifications. This article proves that the role of social facts greatly influences the moral value of individuals in a society/social environment. The thing that distinguishes these two figures is in terms of essence, nature and factors that influence the formation of morality. mile Durkheim is of the view that the value of morality leads to the goal of inculcating the values of obedience and respect based on the collective good. While the nature of morality is evolutionistic (still subject to change) according to circumstances, time and place. Meanwhile, according to $\mathrm{M}$. Quraish Shihab, that the value of morality is more directed to how each individual plays his role as a servant of Allah SWT. who believes and fears Him, both in the relationship between himself and God, as well as himself and other individuals. While the nature of morality is absolute (absolute), dynamic (easy to adjust) and relevant (accepted in every condition). Factors that affect his morality are everything he understands from the social environment, nature and others, especially from his parents as the first teachers in his life.
\end{abstract}

Keywords: Morality, Social, mile Durkheim, M. Quraish Shihab

\begin{abstract}
ABSTRAK
Artikel ini bertujuan untuk melihat bagaimana pembentukan moralitas kemanusiaan dilihat dari fakta sosialnya Émile Durkheim dan ayat-ayat sosialnya M. Quraish Shihab. Penelitian ini menggunakan pendekatan fenomenologi dengan mengkaitkan prinsip-prinsip fundamental, yaitu realitas objektif dan kenyataan sosial yang diintegrasikan dengan obyektifis tradisionalis dan obyektifis modernis. Artikel ini membuktikan bahwa peranan fakta sosial sangat berpengaruh terhadap nilai moralitas pada individu yang ada dalam suatu masyarakat / lingkungan sosial. Hal yang membedakan dari kedua tokoh ini adalah dari segi esensi, sifat dan faktor yang mempengaruhi pembentukan moralitas. Émile Durkheim berpandangan bahwa nilai moralitas mengarah kepada tujuan penanaman nilai-nilai kepatuhan (obedience) dan nilai hormat (respect) berdasarkan kebaikan kolektif. Sedang sifat dari moralitasnya bersifat evolusionistis (masih bisa berubah) sesuai dengan keadaan, waktu dan tempat. Sedangkan menurut M. Quraish Shihab, bahwasanya nilai moralitas lebih mengarah kepada bagaimana setiap individu memainkan perannya sebagai hamba Allah SWT. yang beriman dan bertakwa kepada-Nya, baik itu hubungan antara dirinya dengan Tuhan, maupun dirinya dengan individu yang lain. Sedang sifat dari moralitasnya bersifat absolut (mutlak), dinamis
\end{abstract}


(mudah menyesuaikan) dan relevan (diterima pada setiap kondisi). Faktor yang mempengaruhi moralitasnya segala hal yang ia pahami dari lingkungan sosial, alam dan lainnya terutama dari kedua orangtuanya sebagai guru pertama dalam kehidupannya.

Kata kunci: Moralitas, Sosial, Émile Durkheim, M. Quraish Shihab 


\section{PENDAHULUAN}

Cita-cita bangsa Indonesia adalah menjadi negara besar, kuat, disegani dan dihormati keberadaannya di tengah-tengah bangsa-bangsa di dunia. Setelah 73 tahun merdeka pencapaian cita-cita ini belum menunjukan tandatanda menggembirakan. Optimisme mencapai cita-cita itu terus-menerus dihadapkan pada berbagai macam tantangan. Semangat nasionalisme yang dimiliki founding fathers bangsa ini dalam menegakkan dan membangun Negara Kesatuan Republik Indonesia seakan-akan tidak dapat diimbangi karena begitu banyaknya persoalan-persoalan yang harus diselesaikan bangsa ini. Era globalisasi dengan ikon teknologi, di satu sisi telah membantu percepatan kemajuan bangsa. Namun demikian, seiring dengan hal ini, dirasakan juga dampak yang tidak diharapkan di dalam kehidupan demokrasi. Demikian juga halnya terhadap nilai-nilai kebangsaan, dalam beberapa hal mulai bergeser keluar dari norma-norma yang dijunjung tinggi bangsa.

Kondisi masih jauhnya bangsa ini dari cita-cita yang ditujunya antara lain bersumber dari karakter yang dimiliki bangsa. Perilaku dan tindakan yang kurang atau bahkan tidak berkarakter, telah menjerat semua komponen bangsa mulai dari lembaga Legislatif, Eksekutif, Yudikatif hingga masyarakat awam. Pada masa sekarang, sifat-sifat kepahlawanan, perilaku mengutamakan kepentingan masyarakat luas dan mempertahankan keutuhan bangsa seringkali bergeser kearah sifat-sifat yang mementingkan kepentingan individu dan kelompok. Akibatnya, berlangsung kekeliuran orientasi yang merusak tatanan kehidupan berbangsa.

Terbangunnya orientasi dalam tujuan kehidupan seseorang tidak akan jauh dari proses perkembangan manusia itu sendiri mulai sejak dalam kandungan hingga pada saat inilah yang membentuk perkembangan seseorang yang akhirnya perkembangan ini secara tidak langsung membuat pola pikir seseorang terhadap suatu realita yang ia hadapai. Dinamika kehidupan seseorang pasti akan sangat dekat dan selalu berkaitan dengan aspek rohani maupun jasmaninya aturan Allah yang disebut "sunnatullah". Dalam proses perkembangannya manusia dituntut untuk dapat menyesuaikan diri dengan segala hal yang ada disekitarnya, sehingga dia bisa menjadi makhluk yang dapat menjalankan tugasnya sebagai khalifah di dunia ini, yaitu dengan proses pembelajaran dan pendidikan.

Pelaksanaan pembelajaran erat kaitannya dengan penanaman nilai, juga sangat erat sekali dengan bagaimana cara interaksi sosial yang terjadi di dalamnya, sehingga nilai-nilai baik tak dipandang tabu lagi dalam kehidupan bermasyarakat. Pastinya, diperlukan suatu pembiasaan yang terus berulang-ulang yang berujung kepada adanya tindakan berpola / value yang berada di dalam bawah sadar individu. Maka respon yang keluar baik secara tindakan, kelakuan, maupun 
ucapan akan terealisasikan secara spontanitas, tanpa adanya suatu rekayasa kelakuan maupun ucapan.

Adanya kelainan moralitas yang berlainan dengan apa yang diharapkan pendidikan, pastinya ini memberikan dampak dalam dunia pendidikan dan akan memikirkan kembali tentang hal apa yang menjadi dasar dari pelencengan proses pembelajaran sehingga keluar dari tujuan pembelajaran itu sendiri. Sebagaimana tujuan pendidikan nasional yaitu yang tercantum dalam Pasal 4 UUSPN No. 20 Tahun 2003, yaitu: "Pendidikan Nasional bertujuan mengembangkan potensi peserta didik agar menjadi manusia beriman dan bertakwa kepada Tuhan Yang Maha Esa, berakhlak mulia, berbudi mulia, sehat, berilmu, kompeten, terampil, kreatif, mandiri, estetis, demokratis, dan memiliki rasa kemasyarakatan dan kebangsaan". ${ }^{1}$ Dari pasal tersebut terlihat ada beberapa aspek yang menjadi acuan pemerintah dalam pengembangan manusia dalam mempersiapkan masyarakat yang cerdas dengan kemampuan dan cerdas dalam moralitas kesehariannya.

Menurut Agus Wibowo, carutmarutnya moralitas anak bangsa bisa kita amati dalam kehidupan seharihari. Contoh yang paling sederhana ketika berlalu lintas, dimana bukan hilangnya ketaatan pada rambu-rambu atau aturan yang ada, tetapi juga sudah sirnanya toleransi dan sopan santun

${ }^{1}$ Samsul Nizar, Sejarah dan Pergolakan Pemikiran Pendidikan Islam: Potret Timur Tengah Era Awal dan Indonesia (Jakarta: Quantum Teaching, 2005), h. 177. antara sesama pengguna jalan. Sebagai contoh bunyi klakson pada sepeda motor atau mobil yang semestinya menjadi tanda peringatan, berubah fungsi menjadi alat pemaksa agar orang lain menyingkir ketika sang pembunyi hendak lewat. Dan terjadi tawuran antar pelajar dan bahkan tawuran antar mahasiswa. ${ }^{2}$ Penyalahgunaan dari yang seharusnya dilakukan ini membuat kesemerautan dari suatu fungsi itu sendiri dalam tatanan ketentuan yang telah disepakati bersama adanya.

Fungsi dari penataan itu sendiri lebih mengarah kepada arah terbentuknya suatu keteraturan yang dikehendaki bersama. Hanya saja dalam membangun keharmonisan dalam hidup di lingkungan masyarakat, tentunya tidak semudah membalikkan telapak tangan. Karena dalam bermasyarakat terdapat banyak kepala dengan pemikiran yang berbeda-beda. Tidak sedikit ingin menghadirkan keharmonisan, tapi terkadang ada juga yang tidak mengikuti ketentuanketentuan yang sudah diberlakukan sebelumnya.

Karena manusia adalah makhluk yang merupakan resultan dari dua komponen (Materi dan Immateri), maka konsepsi itu menghendaki proses pembinaan yang mengacu kearah realisasi dan pengembangan komponen-komponen tersebut. Hingga tercapainya tujuan bersama dari apa yang telah dikonsepkan sebelumnya. Berkaitan dengan hal tersebut, maka

\footnotetext{
${ }^{2}$ Agus Wibowo, Pendidikan Karakter Berbasis Sastra, Cet. 1 (Yogyakarta: Pustaka Belajar, 2013), h. 8.
} 
peranan lingkungan memberikan pengaruh luar biasa dalam terealisasikannya interaksi sosial. Untuk itu, perlu diketahui beberapa pandangan para tokoh tentang peranan apa saja yang mempengaruhi perilaku maupun kemampuan manusia dalam lingkungannya. Tiga dari empat aliran pendidikan, mempercayai akan peran penting pengaruh eksternal (lingkungan) dalam membentuk kepribadian anak. Ada empat aliran pendidikan yang sering dibicarakan, yaitu, Pertama, aliran Empirisme yang dicetuskan oleh Jhon Locke, yang beranggapan bahwa yang mempengaruhi perkembangan manusia atas dasar pengalaman yang ia temukan tanpa melibatkan hal lain. Dengan kata lain pengalaman adalah sumber pengetahuan, sedangkan pembawaan yang berupa bakat tidak diakui. ${ }^{3}$ Aliran ini dikenal dengan nama tabularasa atau kertas putih yang kosong, yang artinya kapan dan dimanapun kita bisa menggambar maupun mencoret-core kertas putih tersebut. Bagaimana bentuk dan banyaknya coretan yang tertuang ke dalam kertas, maka itulah yang nantinya akan terlihat dan diperlihatkan dalam bentuk tindakannya.

Kedua, aliran Nativisme yang dikemukakan oleh Arthur Schopenhauer, Aliran nativisme menyatakan bahwa perkembangan seseorang merupakan produksi dari pembawaan yang berupa bakat. Bakat

3 Syarif Hidayat, Toeri dan Prinsip Pendidikan (Jakarta: Pustaka Mandiri, 2013), h. 6.

Page $\mid 81$ yang merupakan pembawaan seseorang akan menentukan nasibnya. Aliran ini merupakan kebalikan dari aliran empirisme. ${ }^{4}$ Dalam hal ini faktor genetika yang mempunyai kedudukan yang dominan dalam pembentukan seseorang kedepannya, sehingga dia tidak membutuhkan pengalaman langsung dalam memahami sesuatu, hanya cukup membaca buku-buku untuk memberikannya informasi.

Ketiga, naturalisme yang dipelopori oleh J.J. Rousseau. Adalah aliran yang mengemukakan bahwa fenomena alam yang nyata ini terjadi karena ketakutan alam itu sendiri yang berinteraksi sesamanya. ${ }^{5}$ Aliran naturalisme menyatakan bahwa semua anak yang dilahirkan pada dasarnya dalam keadaan baik. Anak menjadi rusak atau tidak baik karena campur tangan manusia (masyarakat). Pendidikan hanya memiliki kewajiban untuk memberikan kesempatan pada anak untuk tumbuh dengan sendirinya. Pendidikan hendaknya diserahkan kepada alam. Dalam mendidik seorang anak hendaknya dikembalikan kepada alam agar pembawaan yang baik tersebut tidak dirusak oleh pendidik. ${ }^{6}$ Dalam hal ini, keadaan alam yang memberikan pengalaman dalam proses pemahamannya, karna sejatinya yang alami itu adalah hal yang paling terbaik

4 Syarif Hidayat, Toeri dan Prinsip Pendidikan, ..., h. 6.

5 Alfian Rokhmansyah, Studi dan Pengkajian Sastra; Perkenalan Awal Terhadap Ilmu Sastra (Yogyakarta: Graha Imu, 2014), h. 58.

6 Syarif Hidayat, Toeri dan Prinsip Pendidikan, ..., h. 7. 
ketimbang ada campur tangan manusia, terutama terkadang manusia membantuk suatu kepentingan yang diajarkan oleh para penerusnya.

Keempat, aliran konvergensi yang dipelopori oleh William Stern. Aliran ini menyatakan bahwa bakat, pembawaan dan lingkungan atau pengalamanlah yang menentukan pembentukan pribadi seseorang. Pendidikan dijadikan sebagai penolong kepada anak untuk mengembangkan potensinya. Yang membatasi hasil pendidikan anak adalah pembawaan dan lingkungan. ${ }^{7}$ Aliran ini merupakan jembatan dari bebrapa aliran yang yang sebelumnya, sehingga kekurangan dari aliran sebelumnya yaitu Empirisme dan Nativisme bisa saling menutupi.

Dari sekian banyak tokoh sosial, Durkheim merupakan tokoh sosial menarik perhatian penulis. Dalam teorinya tentang pembentukan moralitas manusia akibat dari fakta sosial (social fact), moralitas merupakan teori sebuah pembentukan nilai yang berada pada dalam diri manusia, sedangkan fakta sosial yaitu suatu teori yang membahas tentang realita sosial yang terbentuk dari sebuah pembiasaan lingkungan individu yang terjadi di dalamnya. Teori Durkheim ini mirip dengan teori riadhahnya Imam Ghazali yang mengacu pada nilai-nilai al Qur'an dan Hadist, sedangkan Durkheim melihat dari sudut kekhawatiran dirinya sebagai mahluk sosial (Zoon Politicon). Untuk membandingkan teori realitas

7 Syarif Hidayat, Toeri dan Prinsip Pendidikan, ..., h. 7 . fakta sosial Émile Durkheim dalam pembentukan moralitas individu pada suatu lingkungan atau masyarakat, khususnya masyarakat yang ada di Indonesia, penulis menambahkan pula tafsir al Qur'an dari ayat-ayat sosial yang dikarang oleh ulama berkebangsaan Indonesia untuk melihat pemahaman dari tafsir al Qur'an yang menjelaskan sosial dari pandangan yang mempunyai latar budaya Indonesia serta merupakan penafsir pertama yang menggunakan bahasa Indonesia dalam menjelaskan ayat-ayat al Quran.

Penerapan moralitas manusia ini tentunya tidak terlepas dari proses pendidikan yang ada dalam lingkungan sekitarnya baik secara aktif maupun secara pasif. Lingkungan yang memberikan pendidikan secara aktif seperti halnya di dalam sekolah (aktifitas pembelajaran), pemahaman dari guru ngaji dan lain sebagainya. Sedangkan pendidikan secara pasif seperti halnya menonton film, mengobrol dan peristiwa yang terjadi secara spontan yang terjadi di lingkungan sekitarnya. Rutinitas yang ada di lingkungan sekitarnya akan membentuk pola pemahaman tersendiri dalam pembentukan nilainilai moral bagi individu yang ada di dalamnya. Pemahaman tersebut selanjutnya ditransmisikan ke dalam diri individu untuk diaktualisasikan dalam kehidupan nyata.

Sehingga, moralitas sangat dipengaruhi oleh faktor rutin dalam perilaku sosial. Orang mendapat kesan bahwa realitas sosial mempunyai suatu 
faktualitas atau kenyataan, yang dari luar menekan atas individu dan mengatur kelakuannya. Dikatakan oleh Durkheim bahwa realitas sosial terdiri dari "fakta" atau "benda" sosial. Orang takut akan reaksi negative atau hukumannya, kalau mereka tidak menyesuaikan diri. ${ }^{8}$ Durkheim juga menjelaskan bahwa "moralitas merupakan suatu orientasi yang impersonal"9 dan "wewenang" yang ada dalam diri manusia yang merupakan hasil dari pergolakan batin individu tersebut, terutama dalam hal pengambilan tindakan yang merupakan bentuk kebaikan yang nantinya akan diterima oleh individu-individu lain yang berada pada lingkungan ia berada.

Realitas yang terdapat dalam suatu lingkungan sosial atau lingkungan tempat terjadinya interaksi sering dikenal dengan fakta sosial. Fakta sosial (sosial fact) adalah aspekaspek kehidupan sosial yang tidak dapat dijelaskan dalam pengertian biologis atau psikologis dari seorang individu. Fakta sosial bersifat eksternal (berada di luar individu). Karena sifat eksternalnya, fakta sosial merupakan

${ }^{8}$ K.J. Veeger, Realitas Sosial: Refleksi Filsafat Sosial Atas Hubungan IndividuMasyarakat dalam Cakrawala Sejarah Sosiologi (Jakarta: PT Gramedia Pustaka Utama, 1985), h. 142.

9 Sherwood D. Fox, Moral Education, diterjemahkan oleh Lukas Ginting dengan judul Pendidikan Moral; Suatu Studi Teori dan Aplikasi Sosiologi Pendidikan oleh Émile Durkheim (Jakarta: Erlanga, 1990), h. 11.

10 Sherwood D. Fox, Moral Education, diterjemahkan oleh Lukas Ginting dengan judul Pendidikan Moral; Suatu Studi Teori dan Aplikasi Sosiologi Pendidikan oleh Émile Durkheim. ..., h. xi. realitas independen dan membentuk lingkungan objektifnya sendiri. ${ }^{11}$

Dalam pandangan Islam, pendidikan yang ada dalam lingkungan juga merupakan hal yang mengarahkan kepada kebaikan jasmani dan rohani. Kebaikan jasmani lebih kepada bagaimana individu berikap dengan lingkungannya sedangkan kebaikan rohani lebih mengarah kepada bagaimana individu bersikap kepada Sang Pencipta / Tuhan (beribadah). Hal ini berarti bahwa sistem pendidikan Islam harus dibangun atas konsep kesatuan (integrasi) antara pendidikan Qalbiyah dan Aqliyah sehingga mampu menghasilkan manusia yang pintar secara intelektual dan terpuji secara moral. ${ }^{12}$ Keselarasan tersebut yang menjadi harapan dalam Islam.

Keselarasan moral tersebut hendaknya dibuat konsep-konsep secara ilmiah untuk memudahkan dalam memahami dan mencapai tujuannya. Kesadaran ilmiah ini sungguh pentingdiwujudkan agar umat Islam mampu membangun rumusan atau konsep-konsep teori berdasarkan inspirasi atau bahan baku dari wahyu ${ }^{13}$ (al Qur'an dan al Hadits) yang nantinya bisa diimplementasikan dilingkungan keluarga. Orang tua berperan penting

${ }^{11}$ M. Amin Nurdin dan Ahmad Abrori, Mengerti Sosiologi, Pengentar Memahami Konsep-Konsep Sosiologi (Jakarta: UIN Jakarta Press, 2003), h. 9.

${ }^{12}$ Al-Rasidin dan Samsul Nizar, Filsafat Pendidikan Islam Pendekatan Historis, Teoritis dan Praktis (Jakarta: Ciputat Press, 2005), h. 21.

13 Mujamil Qomar, Epistimologi Pendidikan Islam; dari Metode Rasional hingga Metode Kritik, Cet. III (Jakarta: Erlanga, 2007), h. 176 . 
membimbing dan mendidik anak, ${ }^{14}$ untuk nantinya diintegrasikan dengan tujuan pendidikan nasional. Sehingga adanya kolaborasi dalam penerapan nilai-nilai untuk mencapai generasi manusia yang mempunyai nilai moralitas kemanusiaan.

Untuk itu penulis merasa penting dalam mengingatkan kembali nilai-nilai yang merupakan tujuan dalam pendidikan Islam. Maka penulis mengambil judul dalam penelitian ini yaitu "Moralitas Kemanusiaan Berdasarkan Fakta Sosial Émile Durkheim dan Ayat-ayat Sosial M. Quraish Shihab”.

\section{PEMBAHASAN}

\section{A. Idealnya Moralitas \\ Kemanusiaan Menurut Émile Durkheim}

Unifikasi Eropa menjadi suatu fenomena paling mencolok dalam zaman kita. Berabad-abad sebelumnya, Eropa menjadi kancah peperangan. Situasi bermusuhan ini meluas dan memuncak sampai Perang Dunia I dan II. Biang keladi adalah nasionalisme beberapa negara besar, khususnya Jerman, Perancis dan Inggris. ${ }^{15}$ Revolusi Perancis membawa dobrakan tentang prinsip kemerdekaan dalam dimensi negara dan masyarakat: di satu pihak, negara

\footnotetext{
14 Chairinniza Graha, Keberhasilan Anak di Tangan Orangtua; Panduan bagi orangtua untuk Memahami Perannya dalam Membantu Keberhasilan Pendidikan Anak, Cet. I (Jakarta: PT. Elex Media Komputindo, 2007), h. 10.

${ }^{15}$ K. Bertens, Sketsa-Sketsa Moral, Cet. I (Yogyakarta: Kanisius, 2004), h. 45.
}

wajib menghormati kebebasan suara hati individu; di lain pihak, negara hasil Revolusi Perancis, Monarki Konstitusional, bukan lagi semata-mata kekuatan pemaksa yang berhadapan dengan individuindividu sebagai suatu yang asing dan lahiriah, melainkan merupakan ekspresi pewujudan nyata kebebasan individu dalam medan masyarakat. $^{16}$ Dengan adanya Revolusi Perancis seperti itu, mengubah cara pandangan orang terhadap nilai moralitasnya.

Dua teori moral yang berlaku di Prancis pada saat itu yang berlaku adalah:

1. Kaum Spiritual seperti pengikut Kant, menggambarkan pengalaman moral sebagai suatu fakta khusus, tetapi bersifat transenden. Mereka menganggap manusia bukan sebagai anggota alam.

2. Kaum Utilitiran yang melihat penjelasan moral secara naturalistis sebagai suatiu kemungkinan.

Durkheim memilih jalan tengah dan menghapus jarak antara manusia dan alam, dan dengan itu memungkinkan penjelasan tentang moral dan religi secara sosiologi. Ia setuju dengan kaum Idealis, bahwa pengalaman moral ini tidak dapat dikembalikan (dipulangkan) pada alam. Ia sependapat dengan aliran

16 Frans Magnis Suseno, Pijar-Pijar Filsafat; dari Gatholoco ke Filsafat Perempuan dari Adam Müler ke Postmodernisme, Cet. I (Yogyakarta: Kanisius, 2005), h. 87. 
naturalis dengan menempatkan gejala-gejala kemanusiaan seperti kebudayaan, pengetahuan, masyarakat, religi dan moral dalam dunia alam. Jika manusia merupakan anggota alamiah maka gejala-gejala kemungkinan dapat diselidiki secara alamiah dan pada peneyelidikan atau studi tentang manusia dan masyarakat dapat diterapkan metode positif. ${ }^{17}$ Dalam pandangan pada metode positif ini, memungkinkan nilai kebenaran yang terjadi pada suatu lingkungan tanpa adanya kejadian yang berasal dari angan-angan (impian atau khayalan) saja.

Ada beberapa hal yang melatar belakangi perhatian Durkheim dalam masalah konsensus dan moralitas, bukan saja atas dasar keadaan politik di Perancis saat itu sehingga menewaskan anak satusatunya yang dipicu karena Perang Dunia I, melainkan juga karena ada pergeseran sosial, dampak dari adanya industralisasi dan kapitalisme saat itu.

Tentang "ilmu moralitas" Durkheim pernah menulis bahwa karena ketentuan moral dan hukum pada dasarnya memantulkan keperluan sosial yang hanya bisa dimasukkan oleh masyarakat itu sendiri -sesuatu yang berdasarkan pada "Pandangan Kolektif” - maka bukanlah tugas kita mendapatkan (ketentuan)

${ }^{17}$ Djuretna A. Imam Muhni, Moral dan Religi menurut Émile Durkheim dan Henri Bergson (Yogyakarta: Kanisius, 1994), h. 37. etika dari ilmu pengetahuan, melainkan membentuk suatu ilmu tentang etika. ${ }^{18}$ Etika merupakan tata nilai yang terkandung dalam suatu lingkungan sosial yang sering dikenal dengan istilah norma. Norma inilah yang menjadi acuan bersosialisasi dalam bermasyarakat. But if there is one fact that history has atau the general character of the morality--------- of its organization.

Selanjutnya Durkheim mengatakan: "Manusia yang percaya, takwa kepada Tuhan yang Maha Esa, karena ia berterimakasih dan percaya bahwa Tuhanlah yang menciptakannya, khususnya mengenai jiwanya. Kita juga mempunyai sebab-sebab yang sama untuk berterimakasih dan takwa kepada kolektivitas". ${ }^{19}$ Tuhan, yang adalah pusat kehidupan religius, yang juga merupakan jaminan tata moral tertinggi. ${ }^{20}$

Pandangan moral dan agama menurut Émile Durkheim:

1. Masyarakat merupakan sumber dan dasar segala-galanya, yang di dalamnya individu sama

${ }^{18}$ Taufik Abdullah dan A. C. Van Der Leeden, Durkheim dan Pengantar Sosiologi Moralitas (Jakarta: Yayasan Obor Indonesia, 1986), h. 2-3.

19 Djuretna A. Imam Muhni, Moral dan Religi menurut Émile Durkheim dan Henri Bergson, ..., h. 41.

${ }^{20}$ Émile Durkheim, Pendidikan Moral: Suatu Studi Teori dan Aplikasi Sosiologi Pendidikan, trans. oleh Lukas Ginting (Jakarta: Erlanga, 1990), h. 6. 
sekali tidak mempunyai arti dan kedudukan.

2. Moral memiliki tiga unsur pokok, yang pertama adalah disiplin. Tanpa disiplin kehidupan tidak berarti. Kedua adalah kesetiaan terhadap kelompok dan ketiga kesadaran akan perbuatan moral.

3. Moral bersifat murni duniawi kemasyarakatan. Tidak ada hubungan dengan apa yang bersifat adikodrati. Bidang moral merupakn kewajiban yang sudah tertentu secara tradisional. Sumber moral adalah masyarakat.

4. Religi adalah masyarakat yang disakralkan. Religi adalah imanen (yang ada di dalam), tidak berdasarkan wahyu Illahi. Ia berfungsi hanya sebagai penguat atau daya pertahanan yang sudah ada. ${ }^{21}$

In the conclusion of Elementary Forms Durkheim argue that religion is not some historic phenomenon destined soon to fade away. The existence of society itself depends on the recurrence of periodic ritual, and only through such events can the sentiments of individuals be united: ${ }^{22}$

21 Djuretna A. Imam Muhni, Moral dan Religi menurut Émile Durkheim dan Henri Bergson, ..., h. 15-16.

${ }_{22}$ Émile Durkheim, Durkheim on Morality and Society Selected Writings (Chicago: The University of Chicago Press, 1973), h. xlix.
Dalam penutup buku Elementary Forms Durkheim berpendapat bahwa agama adalah sejarah beberapa fenomena tidak ditakdirkan untuk segera memudar. Keberadaan masyarakat itu sendiri tergantung pada ritual pengulangan periodik, dan hanya melalui peristiwa tersebut bisa menjadi perasaan individu yang disatukan. ${ }^{23}$

Dengan demikian peranan agama dalam pengaplikasiannya di masyarakat mengikat solidaritas antar individu di dalamnya, yang artinya kelompok yang terbentuk di dalam masyarakat bukan sekedar ada kepentingan bersama, melainkan ada suatu yang dianggap baik yang ingin selalu ada dalam lingkungannya dan kebaikan tersebut terjaga dan terlestarikan oleh penerusnya.

While Durkheim could see no ready social or political solution to this moral problem, he believed that only a special type of consciousness based on charity and human sympathy may overcome the tendency to judge the moral worth of a person in terms of their social background. ${ }^{24}$

Sementara Durkheim melihat tidak ada kesiapan solusi sosial atau politik untuk masalah moral,

23 Diterjemahkan oleh Febria Afia Rahmah, Mahasiswa Magister Pendidikan Bahasa Inggris UIN Syrif Hidayatullah Jakarta, 2018.

${ }^{24}$ Émile Durkheim, Professional Ethics and Civic Morals (London: The Taylor \& Francis e-Library, 2003), h. 28. 
ia percaya bahwa hanya ada jenis khusus dari kesadaran berdasarkan amal dan simpati manusia yang dapat mengatasi kecenderungan untuk menilai nilai moral seseorang dalam hal latar belakang sosial mereka. ${ }^{25}$

Durkheim pernah mendefinisikan dasar dari kehidupan. Sebagai berikut "The dispersed condition in which the society finds itself results in making its life uniform, languishing and dull. But when a corrobbori takes place, everything changes. Since the emotional and passional faculties of the primitive are only imperfectly placed under the control of his reason and will,he easily loses control of himself... There are at once transports of enthusiasm.." ${ }^{126}$

" Kondisi terpencar di dalam mana masyarakat menemukan diri mereka menyebabkan kehidupannya menjadi seragam, merana dan menjemukan. Namun, manakala corrobbori terjadi, semuanya berubah. Oleh karena kemampuan emosional dan gairah orang primitif sangat tidak sempurna ditempatkan di bawah kontrol nalar dan kehendak, ia mudah sekali kehilangan kontrol akan dirinya sendiri. Sekaligus di

25 Diterjemahkan oleh Febria Afia Rahmah, Mahasiswa Magister Pendidikan Bahasa Inggris UIN Syrif Hidayatullah Jakarta, 2018.

26 Émile Durkheim, On Morality and Society (London: The University of Chicago Press, 1973), h. 19. sanalah terjadi sebentuk wahana pengangkut antusiasme." ${ }^{27}$

Menurut penulis dalam hal ini Durkheim melihat bahwa, pertama dalam menyelesaikan masalah moral dalam lingkungan sosial atau politik yaitu dengan adanya kesadaran berdasarkan amal. Kedua, dalam menilai nilai moral seseorang harus berdasarkan nilai simpati manusia itu sendiri, yang artinya besar kecilnya nilai moral seseorang akan terlihat dari besar kecilnya seseorang itu peduli terhadap orang lain, sehingga memberikan nilai empati untuk dirinya. Ketiga bentuk sederhana alur sebuah kehidupan seseorang menurut Durkheim yang seragam yaitu, dikandung, dilahirkan, tumbuh menjadi anak-anak, tumbuh dewasa, menikah, mencari tempat tinggal, punya keturunan dan meninggal. Perubahan terjadi ketika ada perkumpulan dari beberapa orang (bermasyarakat) dan adanya "corrobbori". Corrobbori merupakan nama acara ritual mistik yang ada pada suku pedalaman Australia. Artinya dengan adanya kegiatan di dalam suatu kelompok dan kegiatan itu dianggap sakral bagi kelompoknya, maka akan saling menyatukan diantara setiap anggota kelompok yang ada di dalamnya.

${ }^{27}$ Toni Rudyansyah, Émile Durkheim; Pemikiran Utama dan Percabangannya ke Radchliff-Brown, Fortes, Lèvi-Stauss, Turner, dan Holdbraad (Jakarta: Buku Kompas, 2015), h. 72. 
Durkheim was not saying that the role of the scholar is to carry out his research without regard to his society, but he did argue for the autonomous worth and vitality of the intellectual role. The intellectual is called to hold a mirror to his society, to make conscious its deepest values. ${ }^{28}$

Durkheim tidak mengatakan bahwa peran pelajar (tokoh masyarakat) adalah untuk melakukan penelitian tanpa memperhatikan masyarakat, tapi ia berpendapat untuk nilai otonom dan daya peran intelektual. Intelektual diberikan kepada yang memberikan cerminan kepada masyarakatnya, untuk membuat sadar nilai-nilai terdalam. ${ }^{29}$

Fungsi moralitas adalah dapat membedakan moral yang baik dan tidak baik, ${ }^{30}$ selain itu untuk mencegah individu agar tidak memasuki daerah terlarang; dalam hal ini tidak ada pernyataan yang lebih tegas dari itu. ${ }^{31}$ Dalam pencapaian menuju moralitas dalam masyarakat harus adanya pengetahuan yang menjadi dasar peletakannya.

28 Émile Durkheim, On Morality and Society, .., h. xxxvii.

29 Diterjemahkan oleh Febria Afia Rahmah, Mahasiswa Magister Pendidikan Bahasa Inggris UIN Syrif Hidayatullah Jakarta, 2018.

$3^{30}$ Sony Sukmawan, Menyemai Benih Cinta Sastra, Cet. I (Malang: Universitas Brawijaya Press (UB Press), 2015), h. 2.

${ }^{31}$ Émile Durkheim, Pendidikan Moral: Suatu Studi Teori dan Aplikasi Sosiologi Pendidikan, ..., h.3o. the science of which we outline the plan proposes to reach the moral precepts in their purity and their impersonality. Its object is morality itself, ideal morality poised above individual practices (planant au dessus des actions humaines), not the distortions it suffers when it is incarnated in current practices which can only express it in an inaccurate way. ${ }^{32}$,

sains yang kita ikhtisarkan rencananya berupaya memperoleh aturan moral di dalam bentuk murninya dan impersonalnya. Objeknya adalah moral itu sendiri, moralitas ideal dalam keadaan seimbang di atas praktik individualnya, bukannya distorsinya yang ia alami manakala ia tertitiskan di dalam praktik sedang berlangsung yang hanya mengekspresikan hal itu dalam sebentuk cara yang tidak akurat. ${ }^{33}$

\section{B. Idealnya Moralitas}

\section{Kemanusiaan Menurut}

\section{M.Quraish Shihab}

Menurut M. Quraish Shihab yang dikutip oleh Abd. Haris, membedakan antara istilah etika dan akhlak, beliau mengatakan sebagai berikut:

"akhlak dalam ajaran agama tidak dapat disamakan dengan

${ }^{2}$ Toni Rudyansyah, Émile Durkheim; Pemikiran Utama dan Percabangannya ke Radchliff-Brown, Fortes, Lèvi-Stauss, Turner, dan Holdbraad, ..., h. 85.

33 Toni Rudyansyah, Émile Durkheim; Pemikiran Utama dan Percabangannya ke Radchliff-Brown, Fortes, Lèvi-Stauss, Turner, dan Holdbraad, ..., h. 86. 
etika, jika etika di batasi pada sopan santun antar sesama, serta hanya berkaitan dengan tingkah laku lahiriyah. Akhlak lebih luas maknanya daripada yang telah dikemukakan terdahulu serta mencakup pula beberapa hal yang tidak merupakan sifat lahiriyah. Misalnya, yang berkaitan dengan sikap batin maupun pikiran. Akhlak diniyah (agama) mencakup berbagai aspek, dimulai dari akhlak terhadap Allah, hingga kepada sesama makhluk (manusia, binatang, tumbuh-tumbuhan, dan benda-benda tak bernyawa). ${ }^{34}$ Dalam pandangannya menerangan bahwa akhlak merupakan tingkatan nilai yang paling tinggi yang ada dalam diri manusia. Karna lebih mengedepankan dua aspek, yaitu hablum minannas (berkaitan dengan manusia) dan hablum minawlah (berkaitan dengan Tuhannya).

Betapapun umat Islam berbeda akidah dengan umat Kristiani, menyangkut kedudukan Al Masih, banyak ajaran moral beliau yang sejalan dengan ajaran moral Islam, khususnya bila dipahami konteksnya. Karena itu, seperti yang ditulis Syaikh Muhammad 'Abduh, "Seorang muslim tidak menjadi muslim sebelum dia menjadi Masehi, dalam arti mengakui bahwa Al Masih adalah seorang Nabi Suci, yang diutus

\footnotetext{
${ }^{34}$ Abd. Haris, Etika Hamka; Kontruksi etik berbasis rasional-Religius, Cet. I (Yogyakarta: LkiS Yogyakarta, 2010), h. 41.
}

Allah sebagaimana nabi-nabi lainnya.” Memang wajar, karena "Para nabi bersaudara, hanya ibunya yang berbeda," dengan demikian sabda Nabi Muhammada saw. ${ }^{35}$ Dalam ajaran moral Al Masih pada kondisi sosial dan psikologis saat itu, beliau mengemukakan "Celakalah orang-orang yang kenyang yang tidak menyadari bahwa mereka pada hakikatnya lapar, yang kaya tetapi lupa bahwa mereka butuh. Cintailah musuhmu. Berbuat baiklah kepada yang membencimu. Berkatilah mereka yang mengutukmu. Siapa yang menampar pipi kananmu, serahkan kepadanya pipi kirimu."36 Ini merupakan salah satu ajaran moral yang sulit dipahami dari orang yang bergelimang di dalam kemegahan dan keangkuhan. Selebihnya penulis menganalisa kandungan ayat-ayat sosial yang mempunyai nilai-nilai moral didalamnya dari hasil pengkalsifikasian ayat-ayat sosial yang ada pada bab sebelumnya.

1. Peranan dan nilai moralitas manusia sebagai makhluk sosial dalam al Quran

Peran manusia sebagai makhluk sosial dalam al Qur'an yang telah diklasifikasikan sesuai dengan ayat-ayat sosial yang berasal dari aplikasi Qur'an, Setelah membaca dari beberapa

35 M.Quraish Shihab, Secercah Cahaya Ilahi; Hidup Bersama Al Quran, ..., h. 42. 36 M.Quraish Shihab, Secercah Cahaya Ilahi; Hidup Bersama Al Quran, ..., h. 43. 
sumber, pmaka dapat disimpulkan bahwa skema bagan dari moralitas yang ada dalam ayat-ayat sosial $M$. Quraish Shihab seperti pada bagan di bawah ini.

Gambar 2.1 Ayat-Ayat sosial M. Quraish Shihab

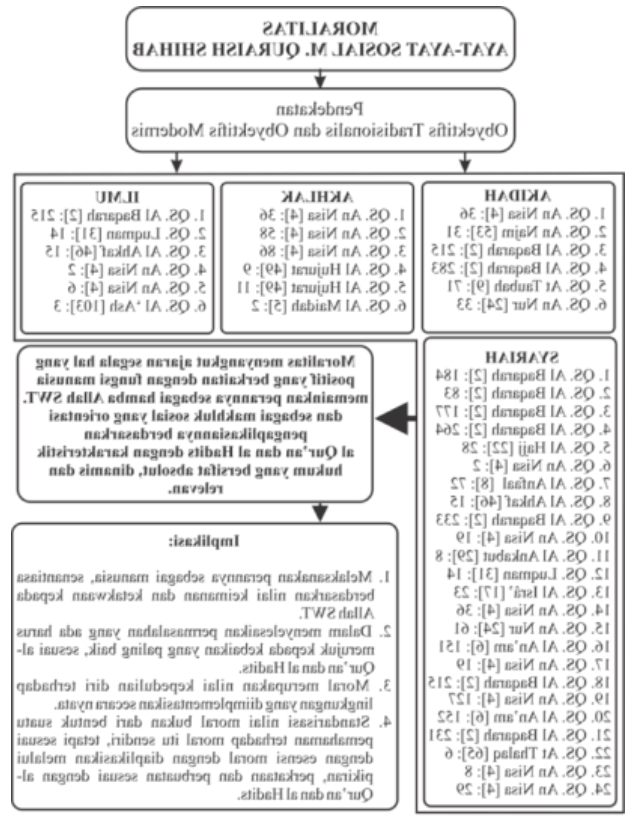

C. Idealnya Moralitas Kemanusian dalam Ayat Al Quran

Dalam Islam terdapat tiga nilai keteladanan utama, yaitu akhlak, adab dan keteladanan. ${ }^{37}$ Istilah akhlak sesungguhnya mencakup makna yang luas, ${ }^{38}$ akhlak merupakan sejumlah mabda' (prinsip) dan nilai yang mengatur perilaku seorang muslim. ${ }^{39}$ Akhlak

37 Abdul Majid dan Dian Andayani, Pendidikan Karakter Persepektif Islam, Cet. I (Bandung: PT. Remaja Rosdakarya, 2011), h. 58.

38 Berliana Kartakusumah, Pemimpin

Adiluhung; Genealogi Kepemimpinan Kontemporer, Cet. I (Jakarta: PT. Mizan Publika, 2006), h. 34.

39 Ali Abdul Halim Mahmud, Karakteristik Umat Terbaik; Telaah Manhaj, Akidah dan Harakah, trans. oleh As'ad Yasin (Jakarta: Gema Insani Press, 1996), h. 96. merujuk kepada tugas dan tanggung jawab selain syari'ah dan ajaran Islam secara umum. Sedangkan kata adab mencangkup segala keunggulan dan keutamaan (fadhâil) serta akhlak mulia. ${ }^{40}$ Menurut al Ghazali yang dikutip oleh Samsul Nizar dan Zaenal Efendi Hasibuan, adab melatih diri lahir dan batinuntuk mencapai kesucian menjadi sufi ${ }^{41}$ Selain itu term adab merujuk kepada sikap yang dihubungkan dengan tingkah laku yang baik. dan keteladanan merujuk kepada kualitas karakter yang ditampilkan oleh seorang muslim yang baik yang mengikuti keteladanan Nabi Muhammad Saw. ${ }^{42}$ Keteladanan merupakan tindakan atau setiap sesuatu yang dapat ditiru atau diikuti oleh seseorang dari orang lain yang melakukan atau mewujudkannya, sehingga orang yang diikuti disebut dengan teladan. ${ }^{43}$ Ketiga nilai inilah yang menjadi pilar pendidikan karakter dalam Islam. ${ }^{44}$ Hukum moral Islam yang tidak saja bersifat mengatur kesalehan individual dalam mengatur hubungan

${ }^{40}$ Masykur, Berguru Adab kepada Imam Malik, Cet. I (Sukabumi: CV. Jejak, 2018), h. 24.

41 Samsul Nizar dan Zaenal Efendi Hasibuan, Pendidik Ideal; Bangunan Character Building, Cet. I (Depok: Kencana, 2018), h. 98.

42 Abdul Majid dan Dian Andayani, Pendidikan Karakter Persepektif Islam, ..., h. 58.

${ }^{43}$ Cece Abdulwaly dan Fauziah Jamilah, Mendidik dengan Teladan yang Baik (Yogyakarta: Diandra Creative, 2016), h. 21.

44 Abdul Majid dan Dian Andayani, Pendidikan Karakter Persepektif Islam, ..., h. 58. 
manusia dengan Allah, melainkan hubungan antara manusia dan sesama manusia. ${ }^{45}$ Nilai dari keteladanan utama yang harus ada dalam diri pribadi seseorang tercermin pada ayat berikut:

1) Q.S. Al Qashash [28]: 77

2) Q.S. Al Ahzab [33]: 21

3) Q.S. At Tahrim [66]: 6-7

Setelah penulis membaca dari beberapa sumber, penulis menyimpulkan bahwa pada gambar di bawah bisa dilihat pandangan Émile Durkheim dengan M. Quraish Shihab dalam memandang nilai-nilai moralitas yang ada dalam lingkungan bermasyarakat.

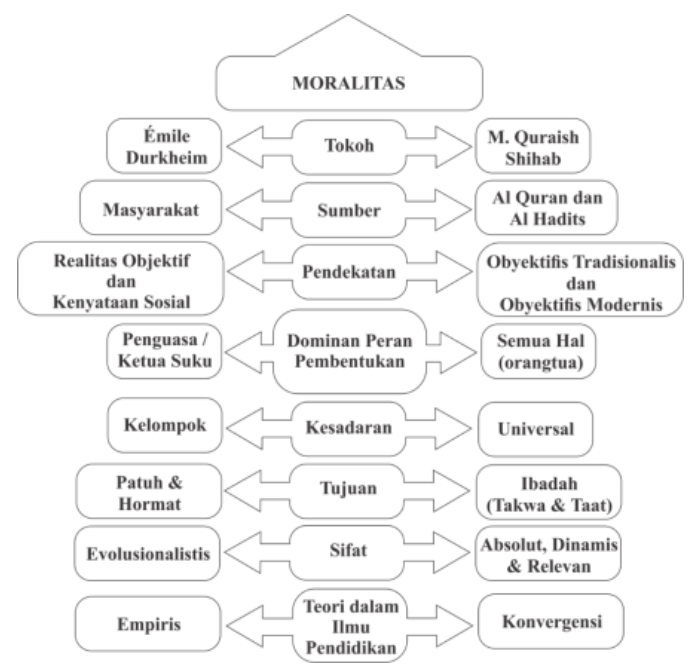

\section{PENUTUP}

Berdasarkan hasil analisis pada pembahasan di atas, maka bisa diambil kesimpulan pada hakikatnya moralitas dalam pandangan Émile Durkheim merupakan tindakan normatif yang berkaitan tentang baik dan buruk yang terbentuk dari fenomena sosial yang

45 Fokky Fuad Wasitaatmaja, Filsafat Hukum; Akar Religiositas Hukum (Jakarta: Kencanam, 2017), h. 57. ada pada suatu wilayah, melainkan juga sebagai kesadaran kolektif yang terbangun secara fungsional dan bersifat evolusionistis. Sedangkan dalam pandangan M. Quraish Shihab merupakan ajaran segala hal yang mempunyai nilai positif yang berkaitan dengan fungsi manusia dalam memainkan perannya sebagai hamba Allah SWT. dan sebagai makhluk sosial yang orientasi pengaplikasiannya berdasarkan al Qur'an dan al Hadits dengan karakteristik hukum yang bersifat absolut, dinamis dan relevan, sehingga pada tempat dan waktu tertentu ataupun yang akan datang ajarannya masih sama dalam hal moralitas dan menyesuaikan keadaan yang sedang terjadi pada masanya.

Konsep yang terbangun pada Moralitas Émile Durkheim merupakan bentuk dari kesepakan bersama dalam suatu wilayah atau kelompok masyarakat tertentu yang mengarah kepada kebaikan bersama yang berlandaskan kepatuhan kepada aturan yang ditetapkan oleh sekelompok orang atau golongan tertentu yang mempunyai kedudukan lebih dengan tujuan menanamkan nilai-nilai kepatuhan (obedience) yang melekat pada diri individu dan menanamkan nilai hormat (respect) terhadap segala ketentuan yang sudah diberlakukan berdasarkan kebaikan kolektif yang ada pada daerah atau wilayah tertentu dalam ruang lingkup suatu kelompok atau masyarakat yang ada di dalamnya. Sedangakan dalam pandangan ayatayas sosial M. Quraish Shihab merupakan bentuk kebaikan yang 
mutlak berdasarkan al Qur'an dan al Hadits dengan berbagai macam-macam dalam mengaplikasiakan kebaikan tersebut baik dengan individu-individu yang ada dalam komponen masyarakat maupun segala hal yang tidak ada urusannya dengan masyarakat, baik dari segi keyakinan, peribadatan dan segala hal yang menjadi komponen dari bagian kehidupan di muka bumi ini. Dalam penerapan moralitas yang ada dalam al Qur'an dan al Hadits ini semuanya tidak lepas dari peran orang tua yang menjadi unsur yang sangat berpotensial dalam menenamkan nilai moralitas.

Dari kedua tokoh ini kita bisa melihat niilai moralitas yang terbangun dari dua segi, yang dengan adanya perbedaan itu bukan untuk melihat siapa yang unggul dan yang kurang unggul, tapi lebih melihat dari alur mana yang bisa diserap dan diimplementasikan ke dalam ruang lingkup pendidikan. Tentunya dengan melihat beragam cara dalam mernerapkan nilai moralitas, pasti ada sisi baik dari setiap teori ini, dengan catatan harus melihat konsekuensi apa yang akan terjadi bilamana dipakai dan tidaknya teori tersebut.

Pada dasarnya kita bisa melihat, iklim yang dibangun oleh sosiolog dalam menerapkan moralitas dan iklim apa yang dibangun oleh pentafsir al Qur'an, tentu akan sangat berbeda dalam penerapan iklim tersebut. Dalam pandangan sosiologis melihat dalam teropong kebiasaan yang mengikat rasa kesadaran, sedang dalam pandangan pentafsir al Qur'an akan meneropong dari segi keykinan hati akan rasa kesadaran yang akan dibiasakan dalam bentuk tindakan. Dengan adanya dua pendekatan ini kita banyak melihat dan berkaca ke luar, khususnya ke yang bukan muslim dalam nenerapkan nilainilai moralitas dengan tujuan untuk melihat celah-celah yang lebih maksimal dalam menerapkan nilai-nilai moralitas dari berbagai pendekatan.

\section{DAFTAR PUSTAKA}

Abdullah, Taufik dan A. C. Van Der Leeden. Durkheim dan Pengantar Sosiologi Moralitas. Jakarta: Yayasan Obor Indonesia, 1986.

Abdulwaly, Cece dan Fauziah Jamilah. Mendidik dengan Teladan yang Baik. Yogyakarta: Diandra Creative, 2016.

Al-Rasidin dan Samsul Nizar. Filsafat Pendidikan Islam Pendekatan Historis, Teoritis dan Praktis. Jakarta: Ciputat Press, 2005.

Bertens, K. Sketsa-Sketsa Moral. Cet. I. Yogyakarta: Kanisius, 2004.

Durkheim, Émile. Durkheim on Morality and Society Selected Writings. Chicago: The University of Chicago Press, 1973.

-_- On Morality and Society. London: The University of Chicago Press, 1973.

-_- Pendidikan Moral: Suatu Studi Teori dan Aplikasi Sosiologi Pendidikan. Diterjemahkan oleh Lukas Ginting. Jakarta: Erlanga, 1990.

- - - Professional Ethics and Civic Morals. London: The Taylor \& Francis e-Library, 2003.

Fox, Sherwood D. Moral Education, diterjemahkan oleh Lukas 
Ginting dengan judul Pendidikan Moral; Suatu Studi Teori dan Aplikasi Sosiologi Pendidikan oleh Émile Durkheim. Jakarta: Erlanga, 1990.

Graha, Chairinniza. Keberhasilan Anak di Tangan Orangtua; Panduan bagi orangtua untuk Memahami Perannya dalam Membantu Keberhasilan Pendidikan Anak. Cet. I. Jakarta: PT. Elex Media Komputindo, 2007.

Haris, Abd. Etika Hamka; Kontruksi etik berbasis rasional-Religius. Cet. I. Yogyakarta: LkiS Yogyakarta, 2010.

Hidayat, Syarif. Toeri dan Prinsip Pendidikan. Jakarta: Pustaka Mandiri, 2013.

Kartakusumah, Berliana. Pemimpin Adiluhung; Genealogi Kepemimpinan Kontemporer. Cet. I. Jakarta: PT. Mizan Publika, 2006.

Mahmud, Ali Abdul Halim. Karakteristik Umat Terbaik; Telaah Manhaj, Akidah dan Harakah. Diterjemahkan oleh As'ad Yasin. Jakarta: Gema Insani Press, 1996.

Majid, Abdul dan Dian Andayani. Pendidikan Karakter Persepektif Islam. Cet. I. Bandung: PT. Remaja Rosdakarya, 2011.

Masykur. Berguru Adab kepada Imam Malik. Cet. I. Sukabumi: CV. Jejak, 2018.

Muhni, Djuretna A. Imam. Moral dan Religi menurut Émile Durkheim dan Henri Bergson. Yogyakarta: Kanisius, 1994.

Nizar, Samsul. Sejarah dan Pergolakan Pemikiran Pendidikan Islam: Potret Timur Tengah Era Awal dan
Indonesia. Jakarta: Quantum Teaching, 2005.

Nizar, Samsul dan Zaenal Efendi Hasibuan. Pendidik Ideal; Bangunan Character Building. Cet. I. Depok: Kencana, 2018.

Nurdin, M. Amin dan Ahmad Abrori. Mengerti Sosiologi, Pengentar Memahami Konsep-Konsep Sosiologi. Jakarta: UIN Jakarta Press, 2003.

Qomar, Mujamil. Epistimologi Pendidikan Islam; dari Metode Rasional hingga Metode Kritik. Cet. III. Jakarta: Erlanga, 2007.

Rokhmansyah, Alfian. Studi dan Pengkajian Sastra; Perkenalan Awal Terhadap Ilmu Sastra. Yogyakarta: Graha Imu, 2014.

Rudyansyah, Toni. Émile Durkheim; Pemikiran Utama dan Percabangannya ke RadchliffBrown, Fortes, Lèvi-Stauss, Turner, dan Holdbraad. Jakarta: Buku Kompas, 2015.

Sukmawan, Sony. Menyemai Benih Cinta Sastra. Cet. I. Malang: Universitas Brawijaya Press (UB Press), 2015.

Suseno, Frans Magnis. Pijar-Pijar Filsafat; dari Gatholoco ke Filsafat Perempuan dari Adam Müler ke Postmodernisme. Cet. I. Yogyakarta: Kanisius, 2005.

Veeger, K. J. Realitas Sosial: Refleksi Filsafat Sosial Atas Hubungan Individu-Masyarakat dalam Cakrawala Sejarah Sosiologi. Jakarta: PT Gramedia Pustaka Utama, 1985.

Wasitaatmaja, Fokky Fuad. Filsafat Hukum; Akar Religiositas 
Jurnal Al Ashriyyah, Volume 6 No 2 Oktober 2o2o: 77-94

Hukum. Jakarta: Kencanam, Yogyakarta: Pustaka Belajar, 2017. 2013 .

Wibowo, Agus. Pendidikan Karakter

Berbasis Sastra. Cet. 1. 